\title{
Article
}

\section{Identification and Validation of Esophageal Squamous Cell Carcinoma Targets for Fluorescence Molecular Endoscopy}

\author{
Xiaojuan Zhao ${ }^{1,2,3,+}$, Qingfeng Huang ${ }^{3,+} \mathbb{D}$, Marjory Koller ${ }^{4} \mathbb{D}$, Matthijs D. Linssen ${ }^{2,5}$, \\ Wouter T. R. Hooghiemstra ${ }^{2,5}$, Steven J. de Jongh ${ }^{2}$, Marcel A. T. M. van Vugt ${ }^{1}$, Rudolf S. N. Fehrmann ${ }^{1}$, \\ Enmin $\mathrm{Li}^{3}$ (D) and Wouter B. Nagengast ${ }^{2, *}$
}

Citation: Zhao, X.; Huang, Q.; Koller, M.; Linssen, M.D.; Hooghiemstra, W.T.R.; de Jongh, S.J.; van Vugt, M.A.T.M.; Fehrmann, R.S.N.; Li, E.; Nagengast, W.B. Identification and Validation of Esophageal Squamous Cell Carcinoma Targets for Fluorescence Molecular Endoscopy. Int. J. Mol. Sci. 2021, 22, 9270 . https://doi.org/10.3390/ ijms 22179270

Academic Editor: Silvie Rimpelova

Received: 20 July 2021

Accepted: 24 August 2021

Published: 27 August 2021

Publisher's Note: MDPI stays neutral with regard to jurisdictional claims in published maps and institutional affiliations.

Copyright: () 2021 by the authors Licensee MDPI, Basel, Switzerland This article is an open access article distributed under the terms and conditions of the Creative Commons Attribution (CC BY) license (https:// creativecommons.org/licenses/by/ $4.0 /)$.
1 Department of Medical Oncology, University Medical Center Groningen, University of Groningen, P.O. Box 30.001, 9700 RB Groningen, The Netherlands; x.zhao01@umcg.nl (X.Z.); m.vugt@umcg.nl (M.A.T.M.v.V.); r.s.n.fehrmann@umcg.nl (R.S.N.F.)

2 Department of Gastroenterology and Hepatology, University Medical Center Groningen, University of Groningen, P.O. Box 30.001, 9700 RB Groningen, The Netherlands; m.d.linssen@umcg.nl (M.D.L.); w.t.r.hooghiemstra@umcg.nl (W.T.R.H.); s.j.de.jongh@umcg.nl (S.J.d.J.)

3 Guangdong Provincial Key Laboratory of Infectious Diseases and Molecular Immunopathology, The Key Laboratory of Molecular Biology for High Cancer Incidence Coastal Chaoshan Area, Shantou University Medical College, Shantou 515041, China; 17qfhuang@stu.edu.cn (Q.H.); nmli@stu.edu.cn (E.L.)

4 Department of Surgery, University Medical Center Groningen, University of Groningen, P.O. Box 30.001, 9700 RB Groningen, The Netherlands; marjorykoller@gmail.com

5 Department of Clinical Pharmacy and Pharmacology, University Medical Center Groningen, University of Groningen, P.O. Box 30.001, 9700 RB Groningen, The Netherlands

* Correspondence: w.b.nagengast@umcg.nl; Tel.: +31-50-361-6161

$+\quad$ These authors contributed equally to this work.

Abstract: Dysplasia and intramucosal esophageal squamous cell carcinoma (ESCC) frequently go unnoticed with white-light endoscopy and, therefore, progress to invasive tumors. If suitable targets are available, fluorescence molecular endoscopy might be promising to improve early detection. Microarray expression data of patient-derived normal esophagus $(n=120)$ and ESCC samples $(n=118)$ were analyzed by functional genomic mRNA (FGmRNA) profiling to predict target upregulation on protein levels. The predicted top 60 upregulated genes were prioritized based on literature and immunohistochemistry (IHC) validation to select the most promising targets for fluorescent imaging. By IHC, GLUT1 showed significantly higher expression in ESCC tissue (30 patients) compared to the normal esophagus adjacent to the tumor (27 patients) $(p<0.001)$. Ex vivo imaging of GLUT1 with the 2-DG 800CW tracer showed that the mean fluorescence intensity in ESCC $(n=17)$ and high-grade dysplasia (HGD, $n=13$ ) is higher $(p<0.05)$ compared to that in low-grade dysplasia (LGD) $(n=7)$ and to the normal esophagus adjacent to the tumor $(n=5)$. The sensitivity and specificity of 2-DG $800 \mathrm{CW}$ to detect HGD and ESCC is $80 \%$ and $83 \%$, respectively (ROC $=0.85$ ). We identified and validated GLUT1 as a promising molecular imaging target and demonstrated that fluorescent imaging after topical application of 2-DG 800CW can differentiate HGD and ESCC from LGD and normal esophagus.

Keywords: fluorescence molecular endoscopy; early detection; squamous high-grade dysplasia; bioinformatics; mRNA profiling

\section{Introduction}

Esophageal cancer is the sixth leading cause of cancer-related deaths worldwide, resulting in an estimated 508,585 deaths worldwide in 2018 [1]. The two dominant histological subtypes in esophageal cancer are adenocarcinoma and squamous cell carcinoma. Around $87 \%$ of global esophageal cancers are of squamous origin. Most of esophageal squamous cell carcinoma (ESCC) were diagnosed in the esophageal cancer belt, which spans 
from Iran to central-northern China [2]. Despite recent advances in treatment regimens, the 5-year disease-specific survival rate of ESCC remains as low as around 19\% [3].

Esophageal squamous dysplasia is the precursor of ESCC. The cumulative ESCC incidence rate for low-grade dysplasia is around $1 \%$. In comparison, the cumulative ESCC incidence rate is $6 \%$ for high-grade dysplasia (HGD, $p$ Tis N0 M0) [4]. After tumor invasion of the muscularis mucosa, the overall risk of metastasis increases and the 5-year overall survival rate of ESCC patients decreases dramatically $[5,6]$. If the tumor is limited to epithelial (EP) and the lamina propria (LPM) layer of intramucosal carcinoma ( $p$ TisT1aEP/LPM N0 M0) [7-9], endoscopic resection offers a minimally invasive option for high-grade dysplasia and ESCC patients, which improves quality of life and increases the 5 -year overall survival rate to around $90 \%$ [5].

Nevertheless, around 70\% of ESCC patients are diagnosed with stage II to IV carcinoma [3]. Chromoendoscopy with Lugol's staining in combination with high-definition white light (HDWL) imaging is considered the best available technique for detecting squamous HGD and ESCC [10]. The Lugol's staining shows brownish-black staining in normal squamous epithelium containing high levels of glycogen but shows less intense or absent staining in squamous HGD or carcinoma as these cells contain little glycogen [10]. A large cohort analysis involving 586 participants for Lugol chromoendoscopy screening reports a detection sensitivity of around 71\% for squamous HGD [11]. Lugol's staining could also lead to retrosternal chest pain and some complications, such as hypersensitivity to iodine, esophagitis, laryngitis, and bronchopneumonia [12]. These complications and the low sensitivity limit the application of Lugol's staining. A recent randomized controlled trial revealed that HDWL endoscopy combined with narrow-band imaging (NBI) system missed all esophageal squamous dysplasia lesions (LGD 0/5; HGD 0/2) [13]. These facts highlight the necessity of improving endoscopic methods to increase detection of high-grade dysplasia and ESCC.

The progression of dysplasia and ESCC from native squamous epithelium is characterized by genomic alterations, such as driver mutations in tumor suppressor genes NOTCH1 and TP53, oncogene NFE2L2, activation of NRF2 pathway and WNT- $\beta$-catenin pathway [14]. Some of the genomic alterations that frequently occur in dysplasia and carcinoma lead to downstream protein overexpression. Fluorescence molecular endoscopy (FME) can target and fluorescently highlight the overexpressed protein targets in dysplasia and carcinoma, which might improve the sensitivity of early detection. FME targeting of excreted factors, such as vascular endothelial growth factor (VEGF) has already been tested in clinical trials on esophageal cancer [15], which demonstrated the safety and feasibility of this technique. However, VEGF is only upregulated in 31\% to $69 \%$ of ESCC lesions and, therefore, is most likely not sensitive enough $[16,17]$. In addition, VEGF is excreted by cells and is mainly located in the stroma which could lead to a false-positive in vivo detection. This restriction could be resolved by using a membrane-bound antigen because FME would target the tumor cell itself. Therefore, in this study, we aim to detect novel imaging protein targets which are membrane-bound and have the potential to improve the detection of esophageal squamous HGD and ESCC lesions by FME.

\section{Results}

2.1. Functional Genomic mRNA Profiling Identifies Upregulated Genes in Esophageal Squamous Cell Carcinoma

We performed a FGmRNA profiling with publicly available expression profiles of 118 ESCC samples and 120 normal esophagus samples (Supplementary Table S1). Class comparison analysis with multivariate permutation testing identified 5364 significantly upregulated genes in ESCC compared to normal esophagus samples (Supplementary Table S2). 


\subsection{Target Prioritization by Literature Search}

The cellular localization of protein products of the top 60 genes is shown in Figure 1. An overview of the literature search results on the top 60 upregulated genes is presented in Supplementary Table S3.

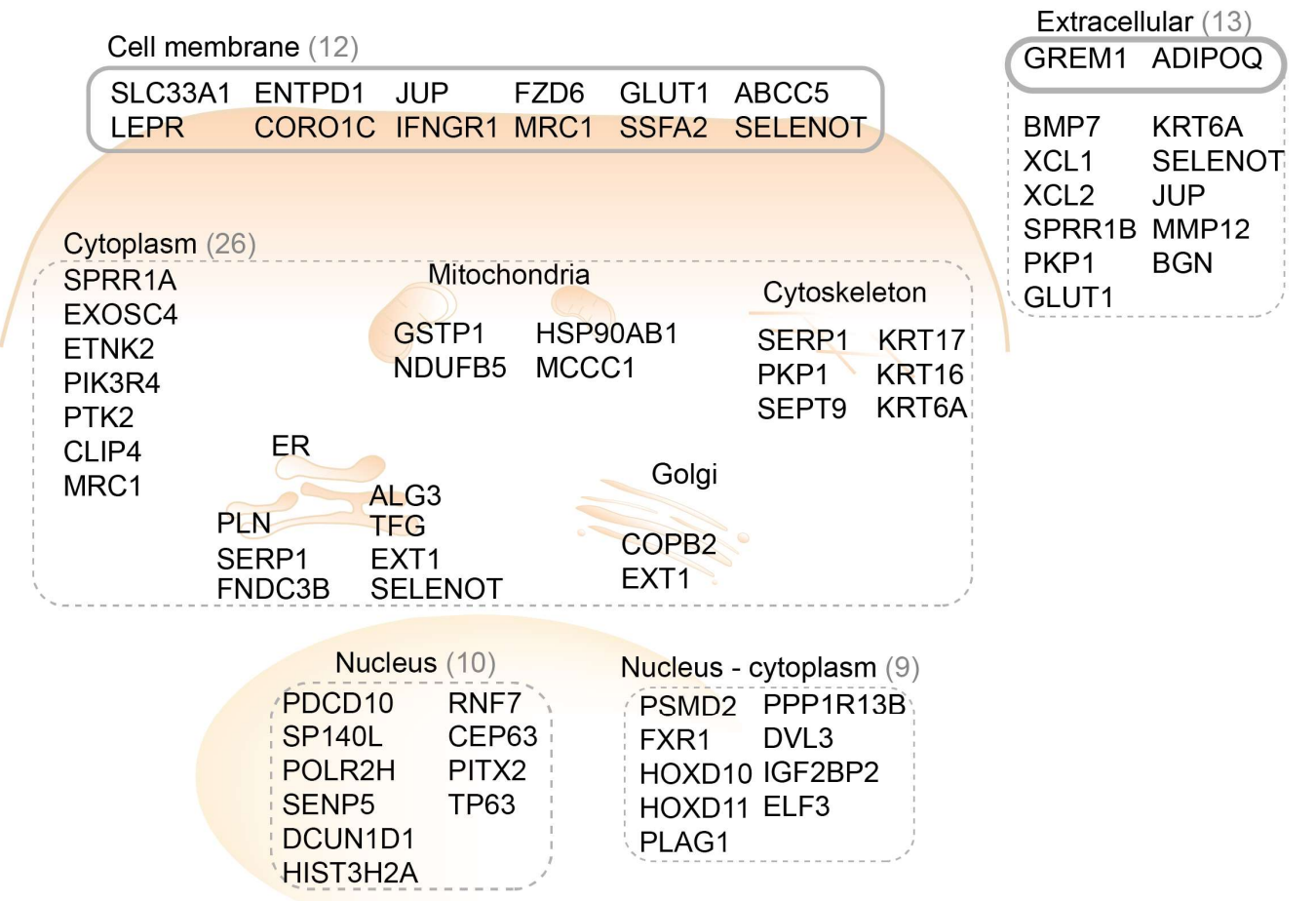

Figure 1. The sub-cellular localization of the protein products of the top 60 FGmRNA-overexpressing genes. The proteins localized on a cell membrane are more easily accessible and especially suitable as imaging targets. ER, endoplasmic reticulum.

The literature search was performed on the first 60 upregulated genes. Among these 60 genes (Supplementary Table S3), 44 genes are described to play a role in carcinogenesis. 12 genes have a known downstream protein overexpression in human esophageal cancer samples. The protein products of 20 genes have shown overexpression in gastrointestinal tumors and these genes could be of interest for ESCC. The encoding proteins of 12 genes are predicted with the cellular location on plasma membrane.

An imaging target for distinguishing ESCC from a normal esophagus should meet two requirements. First, it is preferably localized on the cell membrane, which is more easily accessible for monoclonal antibodies or peptides than intracellular targets. Secondly, the protein should be related to tumorigenesis and have been reported to be overexpressed in esophageal cancer or gastrointestinal cancer compared to normal tissue. According to these requirements, five proteins were defined as possible targets, including FZD6 (Rank 12), GLUT1 (Rank 27), ENTPD1 (Rank 36), LEPR (Rank 43), and IFNGR1 (Rank 48).

\subsection{Evaluation of Five Possible Targets by IHC}

As there is no anti-FZD6 monoclonal antibody commercially available for IHC validation and no fluorescent tracer is available, we at first excluded FZD6 from further validation. We performed IHC of ENTPD1, IFNGR1, LEPR, and GLUT1 on patient's tissue including both ESCC $(n=5)$ and normal esophagus $(n=5)$. Anti-ENTPD1 IHC showed stronger positive staining in stroma cells surrounding esophageal squamous cancer cells compared to normal squamous epithelium cells with localization on cell membrane. However, there was no expression of ENTPD1 detected, neither on the normal esophagus epithelium cells nor on the squamous epithelium cancer cells. Anti-LEPR IHC showed weak positivity in 
normal squamous epithelial cells but much stronger positivity in esophageal squamous cancer cells. However, we tested three anti-LEPR antibodies and they only showed cytoplasm staining, with no cell membrane staining (Figure 2). Anti-IFNGR1 positive staining is found in ESCC tissue but not in normal squamous epithelium. However, after testing two monoclonal anti-IFNGR1 antibodies, we found that both of them show only cytoplasmic staining. Anti-GLUT1 IHC showed that GLUT1 has a high expression on the cell membrane of ESCC with low staining of normal squamous epithelium (Figure 2). Therefore, we decided to expand the cohort to validate GLUT1 expression by IHC with TMA.

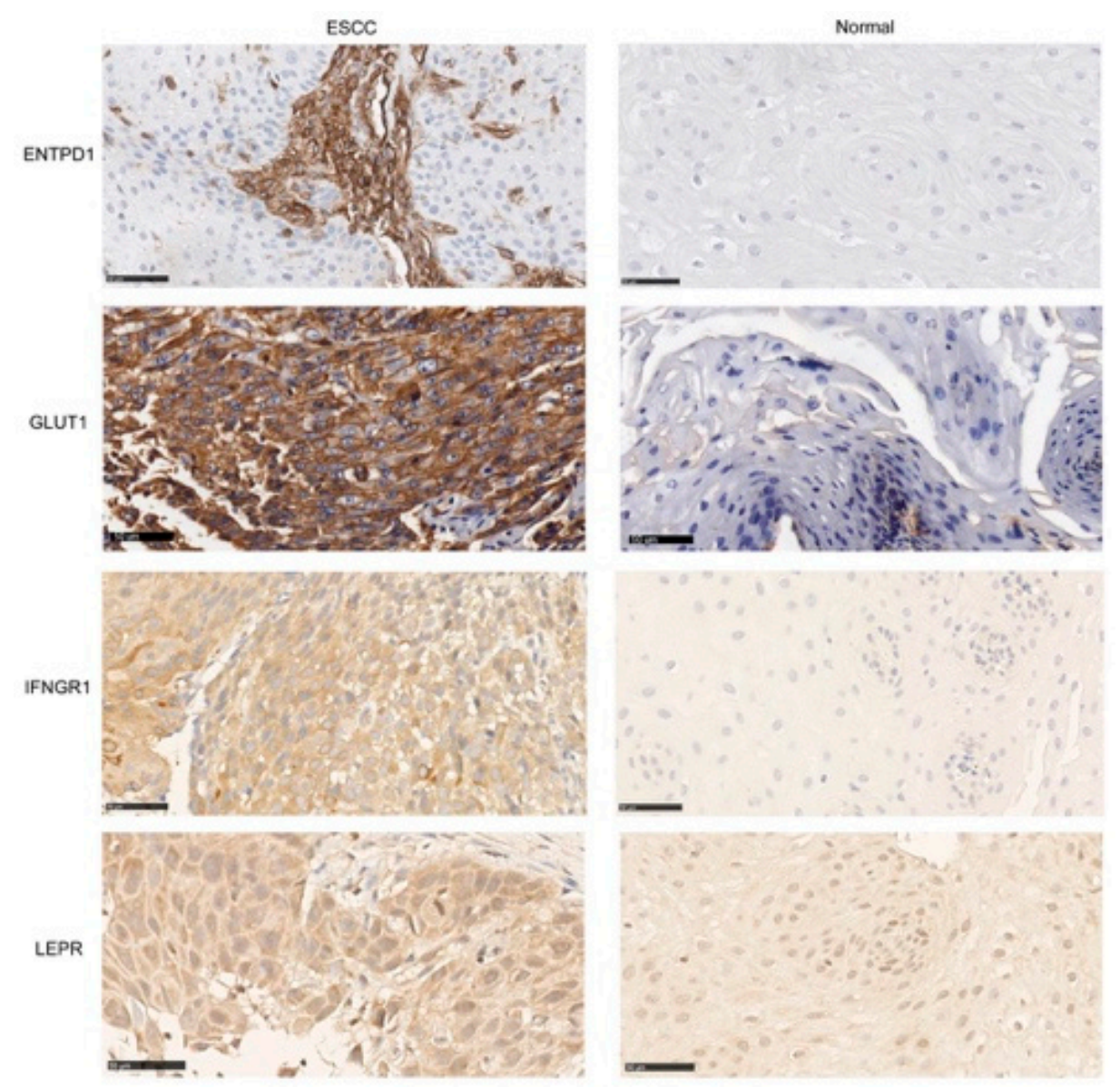

Figure 2. The validation of four candidate genes Representative images of anti-ENTPD1, anti-GLUT1, anti-IFNGR1, anti-LEPR IHC staining results (brown) in ESCC tissue and normal esophagus tissue. Bar: $50 \mu \mathrm{m}$.

\subsection{Ex Vivo Validation of GLUT1 by IHC on TMA: GLUT1 as a Potential Target in ESCC Populations}

To validate if GLUT1 can serve as an imaging target to distinguish ESCC from normal esophagus, we analyzed GLUT1 protein expression in both ESCC and normal esophagus from the same patient by IHC on tissue microarray (Figure 3). GLUT1 showed dominant cell membrane staining in esophageal squamous epithelial cancer cells. For GLUT1, 83.33\% $(25 / 30)$ of ESCC samples show intermediate to high positive intensity, only $16.67 \%(5 / 30)$ of ESCC tissue show low to negative positivity, compared to normal esophagus tissue, which shows $100 \%(27 / 27)$ low-to-negative GLUT1 expression $(p<0.001)$. 
a

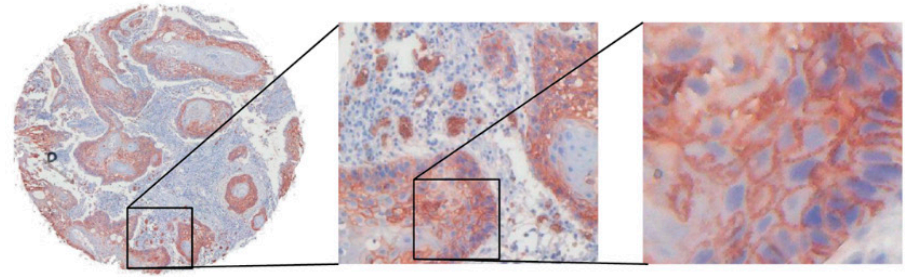

b

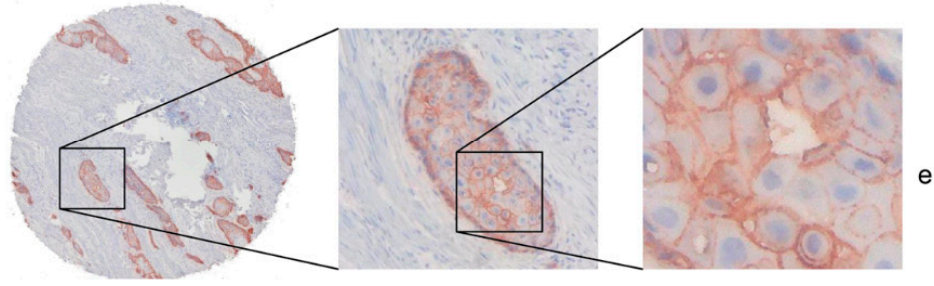

C

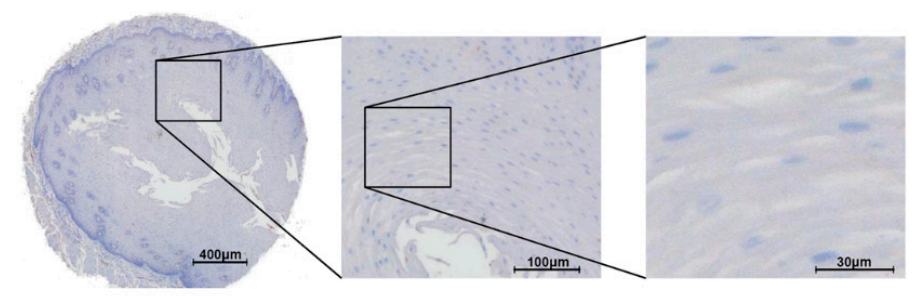

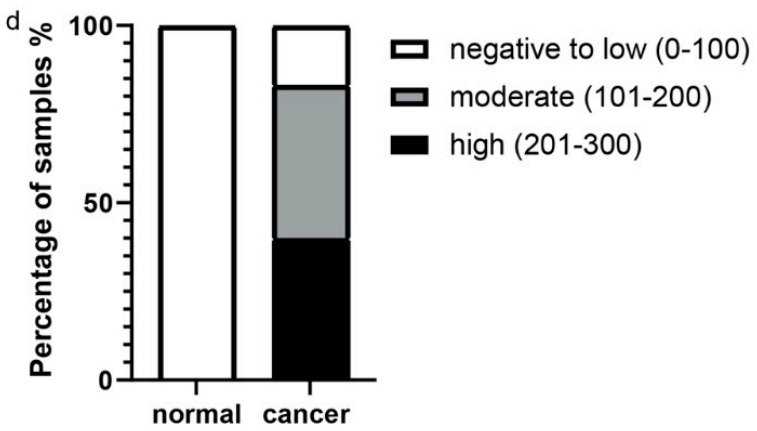

e

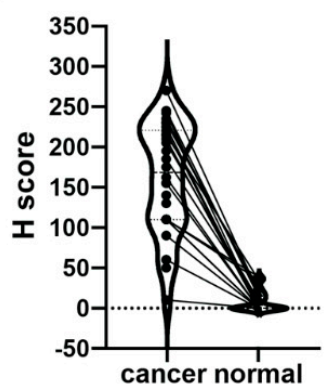

- $\operatorname{cancer}(n=30)$

- $\operatorname{normal}(n=27)$

Figure 3. Anti-GLUT1 immunohistochemistry results in both ESCC and normal esophagus tissue. Representative images of anti-GLUT1 IHC staining results (red) in ESCC patient's tissue ((a,b), different patients for each TMA displayed), and normal esophagus tissue (c). The images of $(\mathbf{a}-\mathbf{c})$ are from the same TMA slice. (d) Bar graph comparison results of H-Score in ESCC tissues to normal esophagus tissues, illustrating a significant difference in staining intensity ( $p$ value $<0.001)$. (e) Comparison of H-Score in ESCC tissues to normal esophagus tissues. Each line connects paired data from the same patient.

\subsection{GLUT1-Related Fluorescence Imaging (2-DG 800CW) of Endoscopy Biopsies Ex Vivo}

The NIR fluorescent glucose analogue, 2-DG $800 \mathrm{CW}$, is a fluorescent marker whose uptake is mediated by GLUT1 [18]. To investigate the uptake in HGD and ESCC, we collected biopsies from patients undergoing surveillance endoscopies $(n=29)$ and sprayed the tracer 2-DG 800CW ex vivo and calculated the mean fluorescence intensity (MFI) in each individual biopsy. The MFI in ESCC $(n=17,4309 \pm 2657)$ tissue showed a significant difference compared to that in low-grade dysplasia (LGD, $n=7,2027 \pm 1190$ ) and normal esophagus $(n=5,1323 \pm 589.7)(p<0.05)$. In addition, the MFI in high-grade dysplasia (HGD, $n=13,4596 \pm 2135$ ) shows a significant difference compared to that in LGD and normal esophagus $(p<0.01)$ There is no significant difference between the MFI for LGD versus normal esophagus ( $p=0.2677)$ and HGD versus ESCC $(p=0.7378)$ (Figure 4a). To determine the sensitivity and specificity of 2-DG $800 \mathrm{CW}$ to detect HGD and ESCC by MFI, a ROC curve was generated which showed an area of 0.8528 (Figure $4 b$ ). If differentiating HGD and ESCC from a normal esophagus with a cut-off MFI value of 2355, the sensitivity and specificity are $80 \%(24 / 30)$ and $83.33 \%(10 / 12)$, respectively. To further correlate the fluorescent signal to histology accurately, we compared the 2-DG $800 \mathrm{CW}$ signal to the H\&E on $4 \mu \mathrm{m}$ slices. We found that most of 2-DG $800 \mathrm{CW}$ fluorescence was located on tumor cells (Figure $5 a, b$ ), while some fluorescence was also found to be along the edges of the biopsy (see Figure 5c,d). Next, we compared the 2-DG 800CW signal to the GLUT1 IHC results and tumor area on $4 \mu \mathrm{m}$ slices and indeed found that the fluorescent signal was not present in all GLUT1 positive areas on the $4 \mu \mathrm{m}$ slices (see Figure $5 \mathrm{a}, \mathrm{b}$ ). We calculated the sensitivity (the percentage of 2-DG $800 \mathrm{CW}$ positive area in GLUT1 positive area) and specificity (the percentage of 2-DG 800CW negative area in GLUT1 negative area) of 2-DG $800 \mathrm{CW}$ in detection of GLUT1 overexpression on $4 \mu \mathrm{m}$ slices of HGD and ESCC biopsies, resulting in a median sensitivity of $23.02 \%$ and a median specificity of $85.43 \%(n=19)$ (see Figure 4c). We also calculated the sensitivity and specificity of 2-DG $800 \mathrm{CW}$ in detection of 
HGD and ESCC on $4 \mu \mathrm{m}$ slices, resulting in a median sensitivity of $18.76 \%$ and a median specificity of $74.18 \%(n=19)$ (see Figure $4 c)$.
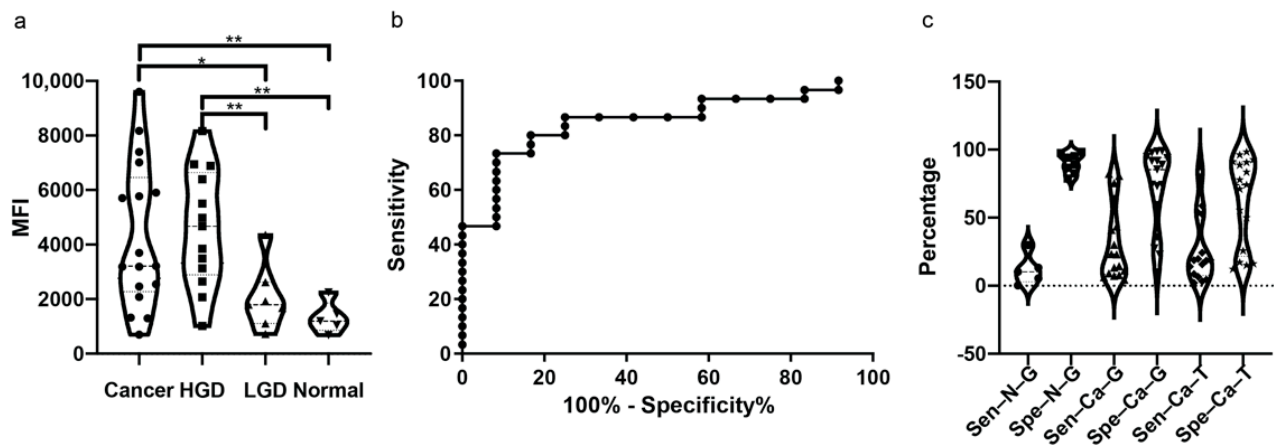

Figure 4. The fluorescent imaging results of 2-DG $800 \mathrm{CW}$ in patients' biopsies. (a) The comparison results of the mean fluorescence intensity (MFI) in four different groups. The two-tailed Mann-Whitney U test is performed. * means $p$ value $<0.05$. ${ }^{* *}$ means $p$ value $<0.01$. (b) The ROC curve analysis on the sensitivity and specificity of applying MFI in whole biopsy to distinguish cancerous tissue (including HGD and ESCC tissue) from LGD/normal tissue. (c) The sensitivity and specificity calculated on $4 \mu \mathrm{m}$ slices. Sen-N-G or Spe-N-G means the sensitivity or specificity, respectively, of 2-DG 800CW to detect GLUT1 expression on normal and LGD tissue; Sen-Ca-G or Spe-Ca-G means the sensitivity or specificity, respectively, of 2-DG 800CW to detect GLUT1 expression on HGD and ESCC tissue; Sen-Ca-T or Spe-Ca-T means the sensitivity or specificity, respectively, of 2-DG 800CW to detect tumor area on HGD and ESCC tissue.

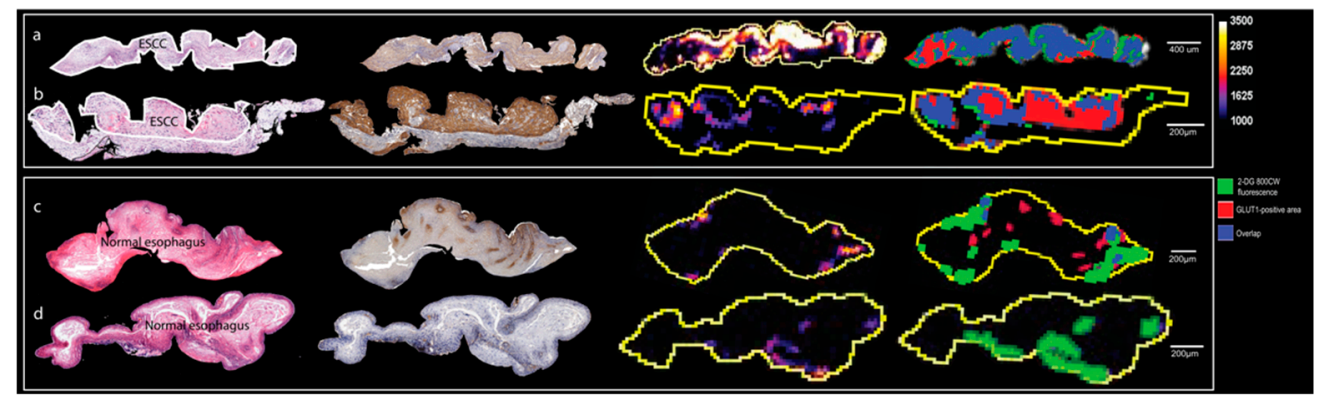

Figure 5. The merge percentage of 2-DG 800CW fluorescence signal in GLUT1 positive area. Each part (a-d) shows serial slices of one tissue block. The first column shows the H\&E images, with cancer tissue delineated with white lines; the second column shows the anti-GLUT1 IHC results, with positive area stained in brown color; the third column shows the fluorescent images of 2-DG 800CW with a calibration bar of 1000 to 3500; the fourth column shows the merge of 2-DG $800 \mathrm{CW}$ fluorescent signal with GLUT1 positive area with a calibration bar of 1000 to 3500 . Part (a,b) are ESCC tissue slices; $(\mathbf{c}, \mathbf{d})$ are normal esophagus tissue slices.

\section{Discussion}

Esophageal squamous cell carcinoma is reported with a high incidence rate and poor prognosis [2,3]. Its precursor stage of high-grade dysplasia shows a high risk of progression to ESCC [4]. Fluorescence molecular endoscopy has the potential to improve the detection of HGD and ESCC by targeting tumor-specific molecules at protein level. By using FGmRNA profiling, we identified novel targets for detection of dysplasia and mucosal ESCC. Of these, GLUT1 showed most promising for molecular imaging and demonstrated that fluorescent imaging after topical application of 2-DG 800CW can differentiate HGD and ESCC from LGD and normal esophagus tissue.

Previously, we performed FGmRNA profiling in colorectal cancer and showed that FGmRNA profiling can obtain useful information from pre-existing data and find a proper new target for molecular imaging [19]. Somatic copy number alterations (SCNAs) participate in the stepwise progression from native squamous epithelium to squamous dysplasia and ESCC [14]. However, the effect of SCNAs on gene expression levels is often overshadowed 
by non-genetic factors, such as physiological circadian rhythm or metabolic factors [20]. The non-genetic transcriptional components were applied as covariates to correct the raw microarray expression data, namely, FGmRNA profiling. The residual gene expression levels (FGmRNA profiles) after correction correlation with SCNAs capture the downstream effect of SCNAs on gene expression levels. In this study, among our top identified genes, $D V L 2, D V L 3, F Z D 6$, and GSK3B are all known target-genes of the Wnt signaling pathway. In addition, ADAM17, ELF3, and EGFR belong to the Notch signaling pathway. The Wnt signaling pathway and the Notch pathway are both known to be involved in the carcinogenesis of ESCC [21,22], which supports the pathophysiological relevance of the identified genes. Trophoblast cell surface antigen-2 (Trop-2) contributes to carcinogenesis and is overexpressed in several cancer types [23]. Nakashima K, et al. reported an overexpression of Trop-2 in ESCC tissue by immunohistochemistry [24], in concordance with our FGmRNA profiles (Rank 335). Sacituzumab govitecan, targeting Trop-2, was developed [25] and under investigation in breast cancer (NCT02574455, NCT03901339) and urothelial cancer (NCT04527991). We present an extensive list of additional genes identified by FGmRNA profiling, which may be the new potential imaging targets (Supplementary Table S2).

After validation of four proteins by IHC, we find that ENTPD1, IFNGR1, LEPR, and GLUT1 show higher expression in ESCC compared to the normal esophagus, which is consistent with FGmRNA profiling results. ENTPD1 was excluded as an FME target as we saw it was expressed in the tumor microenvironment. This is expected as ENTPD1 is an integral component of regulatory T cells, which infiltrate into the tumor stroma. As the differential expression of ENTPD1 is not on epithelial cells, we do not consider ENTPD1 as an ideal target for imaging. According to the literature search, LEPR and IFNGR1 are described to express mostly on the cell membrane, sometimes in cytoplasm. With the antibodies we used, membrane staining was not shown.

GLUT1 is a member of glucose transporter (GLUT) family, which can transport glucose and related hexoses into cancer cells to meet their high metabolic requirement [26]. To date, there are 14 members of the GLUT family reported, among which GLUT1 [27], GLUT2 [28], GLUT3 [27], and GLUT4 [29] have a role in ${ }^{18}$ FDG uptake. The transporters of ${ }^{18} \mathrm{FDG}$ are still controversial and which specific GLUT subtypes are in charge of FDG uptake differs between cancer types. The facts that both the expression of different GLUT proteins and the sensitivity of ${ }^{18}$ FDG-PET varies greatly between different cancer types [26,30], which suggests the molecular imaging of specific GLUT members can improve the detection sensitivity of different cancer types.

IRDye $800 \mathrm{CW}$ conjugated to 2-DG is a fluorescently labeled glucose-derivative tracer with a molecular weight of around $1330 \mathrm{Da}$, which is more than seven-folds higher than that of ${ }^{18} \mathrm{FDG}$ (around $181 \mathrm{Da}$ ). The high uptake of 2-DG $800 \mathrm{CW}$ in cancer is thought to be because of the high metabolic requirement, which is the same as ${ }^{18} \mathrm{FDG}$. Although 2-DG $800 \mathrm{CW}$ is also proven to be transported into cells, its transportation mechanism is still unknown. It is suggested to result from an endocytosis process of GLUT1/2-DG $800 \mathrm{CW}$ complexes and it is also shown to be related to GLUT4 [18]. Our results have shown that the uptake of 2-DG 800CW in HGD and ESCC is significantly higher than in normal squamous epithelium or low-grade dysplasia. Previous reports have shown 2-DG 800CW uptake in breast cancer and prostate carcinoma in mouse models [18,31], while we show its potential role after topical administration in HGD and ESCC cancer with patients-derived endoscopic biopsies. Furthermore, we find that by differentiating HGD and ESCC from normal esophagus tissue at a cut-off MFI value of 2355, the sensitivity and specificity is $80 \%$ and $83.33 \%$, respectively. However, when comparing the fluorescent signal to GLUT1 expression or tumor area on $4 \mu \mathrm{m}$ slices, we find that 2-DG $800 \mathrm{CW}$ is highly specific to detect GLUT1 or a tumor, but the sensitivity is relatively low. We think there are some limitations leading to the low sensitivity on $4 \mu \mathrm{m}$ slices. First, the tracer is sprayed ex vivo on the biopsies but not injected in vivo. Because of the tight junctions between the surface epithelium cells of the esophageal mucosal layer, it is not easy for the tracer to reach cells expressing membrane-bound GLUT1. Second, the incubation time may not be 
long enough for all tracers to bind to GLUT1. Furthermore, 2-DG 800CW is not directly binding to the cell surface site of GLUT1 but it is potentially transported into the cytoplasm by endocytosis [18], which requires the cells to be alive. Therefore, as the tracer is tested ex vivo, a reduction in cell viability may be the cause of reduced tracer uptake.

From our results, we can see that 2-DG $800 \mathrm{CW}$ is a promising tracer after topical application to the mucosa to distinguish high-grade dysplasia and esophageal squamous cell carcinoma from normal squamous epithelium and low-grade dysplasia with a good sensitivity and specificity. However, ESCC was reported with intertumor and intratumor heterogeneity [32,33]. Recently, the first multiplexed FME system was developed, which would enable concurrent imaging of multiple target molecules [34]. Further development of other specific fluorescence tracers for the multiplexed imaging with 2-DG 800CW has the potential to further improve the detection of HGD and mucosal ESCC by fluorescence molecular endoscopy.

\section{Materials and Methods}

\subsection{Identification of Differentially Expressed Genes with Functional Genomic mRNA Profiling}

Microarray expression data of primary patient-derived ESCC and normal esophagus samples generated with the Affymetrix HG-U133 plus 2.0 and the HG-U133A platforms were obtained from the Gene Expression Omnibus database [35]. Pre-processing, normalization, and quality control was performed as previously described [36]. Subsequently, functional genomic mRNA (FGmRNA) profiling was applied to extract the downstream consequences of genetic alterations on gene expression profiles [19]. FGmRNA profiling is a method capable of correcting gene expression data and allows for an enhanced view on the downstream effects of genomic alterations on gene expression levels. To identify genes which are upregulated in ESCC compared to the normal esophagus, we performed a transcriptome-wide class comparison (Welch's $t$-test) between FGmRNA profiles of ESCC and normal esophagus [37-44].

\subsection{Prioritization Strategy}

Based on the FGmRNA results, the top 60 upregulated genes in ESCC were selected for further prioritization based on a literature search [45-125]. First, we searched for the function of the gene and its relation to carcinogenesis. Second, we searched per gene for articles published in English from conception until December 2019. The searching terms used are: HUGO gene symbol of the target under investigation in combination with 'immunohistochemistry' and 'esophageal cancer' or 'gastrointestinal cancer' or 'gastric cancer' or 'colorectal cancer' or 'rectum cancer'. Thirdly, the cellular localization, function, and expression of the protein product was searched in www.proteinatlas.org, www.Genecards.com and www.genetica-network.com (accessed between 1 January 2017 and 31 December 2019) [126]. As we were looking for promising targets for fluorescent molecular endoscopy, the targets should be expressed on cell membrane to be easily accessible. Furthermore, we evaluated if there was already optical molecular imaging research targeting the protein products of the upregulated genes.

\subsection{Immunohistochemistry}

To validate the expression of protein products encoded by upregulated genes, we performed immunohistochemistry (IHC) on tissue microarrays (TMA) made from formalinfixed and paraffin-embedded (FFPE) tissue blocks. The tissue blocks include esophageal squamous cell carcinoma (ESCC, $n=30$ ) and normal esophagus tissue adjacent to ESCC $(n=27)$ collected from patients who underwent esophagectomy between 2012 and 2016 in the affiliated cancer hospital of Shantou University Medical College (SUMC, Shantou, China). We also performed IHC on FFPE slices including normal esophagus $(n=5)$ and ESCC tissue $(n=5)$ from the University Medical Center Groningen (UMCG). All human tissue samples were applied according to the guidelines of Shantou University Medical College (SUMC) ethics board and that of the University Medical Center Groningen 
(UMCG) ethics board (www.ccmo.nl, accessed on 22 December 2016). Five-micron slices (for TMA) and four-micron slices (for normal FFPE slices) were cut and mounted on amino-propylethyoxy-silan-coated glass slides. Secondly, the slices were deparaffinized in xylene and rehydrated in 70\%, 96\%, 99.9\% alcohol, respectively. Thirdly, after conducting heat-induced antigen retrieval using citrate buffer (10 mM, pH 6.0) or EDTA buffer (mM, pH 9.0), we blocked the endogenous peroxidase activity by incubation with a $0.3 \%$ hydrogen-peroxide solution for $30 \mathrm{~min}$. Next, we incubated the slides with the primary antibodies against GLUT1, ENTPD1, LEPR overnight at 4 degrees (GLUT1) or for $1 \mathrm{~h}$ at room temperature (ENTPD1, LEPR, IFNGR1) (Supplementary Table S4). Subsequently, the slices were incubated with the second and third antibodies diluted as 1:50 in PBS with 1\% human $\mathrm{AB}$-serum and $1 \%$ bovine serum albumin (BSA). The incubation lasts for $30 \mathrm{~min}$ with either the second or third antibody. Finally, the slices were specifically stained with 3,3'diaminobenzidine (DAB) substrate chromogen solution or 3-amino-9-ethylcarbazole (AEC) peroxidase substrate solution, followed by hematoxylin nuclei staining. XZ optimized the IHC staining protocols, performed the IHC staining under the supervision of a dedicated gastrointestinal pathologist Dr. Arend Karrenbeld (AK) from the Department of Pathology and Medical Biology, the University Medical Center Groningen. Both positive controls and negative controls (with a specific IgG monoclonal antibody) are conducted in each IHC staining to ascertain specific binding of the antibody.

\subsection{H-Score Calculation}

We score the staining intensities of the epithelial cells according to a 0-3 scale (Supplementary Figure S1). The H-Score of each sample was calculated according to the equation (H-Score $=1 *$ (percentage of cells weakly stained $)+2 *$ (percentage of cells moderately scored) $+3 *$ (percentage of cells strongly stained)). The H-Score range is from 0 to 300 , leading to three categories of $\mathrm{H}$-Score for each tissue sample (0-100 is defined as a negative/low H-Score; $101-200$ = intermediate; 201-300 = high). The H-Scores were independently scored by two researchers $(\mathrm{XZ}, \mathrm{AK})$.

\subsection{GLUT1 Related Fluorescence Imaging Using 2-DG 800CW on Patient-Derived Esophageal Squamous Cell Carcinoma Biopsies}

In total, 29 patients and 42 biopsies were included. We collected 17 ESCC biopsies from 15 patients; 13 high-grade dysplasia biopsies from 12 patients; 7 low-grade dysplasia biopsies from 6 patients, and 5 normal biopsies from 5 patients during endoscopy. In 20 patients, one biopsy per patient was included in the study. In 9 patients, more than one biopsy from each patient were included in the study (In 4 patients, 3 biopsies were included from each patient; in 5 patients, 2 biopsies were included from each patient). The study was approved by the Ethics Committee of Cancer Institute and Hospital, Chinese Academy of Medical Sciences (16-171/1250). All participants received oral and written information before informed consent was obtained. The fresh biopsies were incubated for $5 \mathrm{~min}$ with a solution of 2-DG 800CW in phosphate buffered saline (Li-COR Biosciences, Lincoln, NE, USA; $0.1 \mathrm{nmol} / \mathrm{mL}$ ). After rinsing the tissue with normal saline three times, we scanned the tissue with ChemiDoc ${ }^{\mathrm{TM}}$ MP scanner (Bio-Rad, Hercules, CA, USA; 835/50 nm; exposure time: $5 \mathrm{~s}$ ). After that, we cut each biopsy into $4 \mu \mathrm{m}$ slices and performed H\&E staining with a Hamamatsu scanner (Hamamatsu Photonics, Shizuoka, Japan) and 2-DG 800CW imaging with an Odyssey scanner (Li-COR Biosciences, Lincoln, NE, USA; $800 \mathrm{~nm}$; resolution: $21 \mu \mathrm{m}$ ). To analyze the sensitivity and specificity of 2-DG 800CW to detect GLUT1 expression, antiGLUT1 IHC staining was also performed on the serial $4 \mu \mathrm{m}$ slices for each biopsy and imaged with a Hamamatsu scanner (Hamamatsu Photonics, Shizuoka, Japan).

\subsection{Statistical Analyses}

We compared the FGmRNA expression levels of healthy control to ESCC patients by the two-sample Student $t$-test. To control for false discovery rate, we performed a multivariate permutation (MVP) test with a false discovery rate (FDR) of $1 \%$ and a confidence interval (CI) of $99 \%$. The overexpressing genes were identified and ranked by the level of 
significance in FGmRNA profiles. The H-Score of tissue samples were analyzed using the non-parametric Kruskal-Wallis test (IBM SPSS 23.0.0; RRID:SCR_002865, IBM Corporation, Armonk, NY, USA). $p$-value $<0.01$ was considered significant for H-Score analysis.

\section{Conclusions}

We have shown that our new bioinformatics approach can both identify potential molecular imaging targets and explore the underlying pathophysiological process. We identified and validated that GLUT1 is indeed overexpressed in ESCC and can be targeted by 2 -DG $800 \mathrm{CW}$. This approach has the potential to improve detection of high-grade squamous dysplasia and ESCC by FME during screening endoscopy procedures. Phase 1 clinical trials should further elucidate the potential and safety of 2-DG $800 \mathrm{CW}$ in detecting high-grade dysplasia and ESCC by FME.

Supplementary Materials: The following are available online at https:/ /www.mdpi.com/article/10 $.3390 / \mathrm{ijms} 22179270 / \mathrm{s} 1$.

Author Contributions: Conceptualization, W.B.N. and R.S.N.F.; methodology, R.S.N.F. and W.B.N.; validation, X.Z., Q.H. and S.J.d.J.; formal analysis, M.K.; investigation, X.Z. and Q.H.; resources, M.D.L. and W.T.R.H.; data curation, X.Z. and W.B.N.; writing-original draft preparation, X.Z.; writing—review and editing, Q.H., W.B.N., M.A.T.M.v.V., R.S.N.F., E.L., W.T.R.H. and M.D.L.; visualization, X.Z.; supervision, W.B.N.; project administration, W.B.N.; funding acquisition, E.L. All authors have read and agreed to the published version of the manuscript.

Funding: This study was supported by Grants from the National Cohort of Esophageal Cancer of China (No. 2016YFC0901400).

Institutional Review Board Statement: The study was conducted according to the guidelines of the Declaration of Helsinki, and approved by the Ethics Committee of Cancer Institute and Hospital, Chinese Academy of Medical Sciences (16-171/1250, 22 December 2016).

Informed Consent Statement: Informed consent was obtained from all subjects involved in the study. Written informed consent has been obtained from the patient(s) to publish this paper.

Data Availability Statement: The data presented in this study are available in supplementary material here.

Acknowledgments: We thank Arend Karrenbeld, Pathologist from Department of Pathology and Medical Biology in the University Medical Center Groningen for assistance with pathological analysis. We would also like to show our gratitude to Jiang Gu, a Professor of Shantou University Medical College for sharing their patients' tissues to make TMA slices.

Conflicts of Interest: The authors declare no conflict of interest. The funders had no role in the design of the study; in the collection, analyses, or interpretation of data, in the writing of the manuscript, or in the decision to publish the results.

\section{References}

1. World Health Organization. Cancer Today: Data Visualization Tools for Exploring the Global Cancer Burden in 2020. Available online: https:/ /gco.iarc.fr/today/home (accessed on 20 August 2021).

2. Arnold, M.; Soerjomataram, I.; Ferlay, J.; Forman, D. Global incidence of oesophageal cancer by histological subtype in 2012. Gut 2015, 64, 381-387. [CrossRef]

3. Then, E.O.; Lopez, M.; Saleem, S.; Gayam, V.; Sunkara, T.; Culliford, A.; Gaduputi, V. Esophageal Cancer: An Updated Surveillance Epidemiology and End Results Database Analysis. World J. Oncol. 2020, 11, 55-64. [CrossRef]

4. Wei, W.Q.; Hao, C.Q.; Guan, C.T.; Song, G.H.; Wang, M.; Zhao, D.L.; Li, B.Y.; Bai, W.L.; Hou, P.Y.; Wang, J.W.; et al. Esophageal Histological Precursor Lesions and Subsequent 8.5-Year Cancer Risk in a Population-Based Prospective Study in China. Am. J. Gastroenterol. 2020, 115, 1036-1044. [CrossRef] [PubMed]

5. Yamashina, T.; Ishihara, R.; Nagai, K.; Matsuura, N.; Matsui, F.; Ito, T.; Fujii, M.; Yamamoto, S.; Hanaoka, N.; Takeuchi, Y.; et al. Long-term outcome and metastatic risk after endoscopic resection of superficial esophageal squamous cell carcinoma. Am. J. Gastroenterol. 2013, 108, 544-551. [CrossRef] [PubMed]

6. $\quad$ Akutsu, Y.; Uesato, M.; Shuto, K.; Kono, T.; Hoshino, I.; Horibe, D.; Sazuka, T.; Takeshita, N.; Maruyama, T.; Isozaki, Y.; et al. The overall prevalence of metastasis in T1 esophageal squamous cell carcinoma: A retrospective analysis of 295 patients. Ann. Surg. 2013, 257, 1032-1038. [CrossRef] 
7. Kitagawa, Y.; Uno, T.; Oyama, T.; Kato, K.; Kato, H.; Kawakubo, H.; Kawamura, O.; Kusano, M.; Kuwano, H.; Takeuchi, H.; et al. Esophageal cancer practice guidelines 2017 edited by the Japan Esophageal Society: Part 1. Esophagus 2019, 16, 1-24. [CrossRef] [PubMed]

8. Rice, T.W.; Kelsen, D.; Blackstone, E.H.; Ishwaran, H.; Patil, D.T.; Bass, A.J.; Erasmus, J.J.; Gerdes, H.; Hofstetter, W.L. Esophagus and esophagogastric junction. In AJCC Cancer Staging Manual, 8th ed.; Amin, M.B., Edge, S., Greene, F., Byrd, D.R., Brookland, R.K., Washington, M.K., Gershenwald, J.E., Compton, C.C., Hess, K.R., Sullivan, D.C., et al., Eds.; Springer: New York, NY, USA, 2016; Chapter 16, pp. 185-202.

9. Lam, A.K.; Ochiai, A.; Odze, R.D. Tumours of the oesophagus: Introduction. In WHO Classification of Tumours Digestive System Tumours, 5th ed.; Odze, R.D., Lam, A.K., Ochiai, A., Washington, M.K., Eds.; IARC: Lyon, France, 2019; Chapter 2, pp. 28-29.

10. Kondo, H.; Fukuda, H.; Ono, H. Sodium thiosulfate solution spray for relief of irritation caused by Lugol's stain in chromoendoscopy. Gastrointest. Endosc. 2001, 53, 199-202. [CrossRef] [PubMed]

11. Li, J.; Xu, R.; Liu, M.; Cai, H.; Cao, C.; Liu, F.; Cai, H.; Cao, C.; Liu, F.; Li, F.; et al. Lugol chromoendoscopy detects esophageal dysplasia with low levels of sensitivity in a high-risk region of China. Clin. Gastroenterol. Hepatol. 2018, 16, 1585-1592. [CrossRef] [PubMed]

12. Ide, E.; Carneiro, F.O.; Frazão, M.S.; Chaves, D.M.; Sallum, R.A.; de Moura, E.G.; Sakai, P.; Cecconello, I.; Maluf-Filho, F. Endoscopic detection of early esophageal squamous cell carcinoma in patients with achalasia: Narrow-band imaging versus Lugol's staining. J. Oncol. 2013, 2013, 736756. [CrossRef] [PubMed]

13. Gruner, M.; Denis, A.; Masliah, C.; Amil, M.; Metivier-Cesbron, E.; Luet, D.; Kaasis, M.; Coron, E.; Le Rhun, M.; Lecleire, S.; et al. Narrow-band imaging versus Lugol chromoendoscopy for esophageal squamous cell cancer screening in normal endoscopic practice: Randomized controlled trial. Endoscopy 2021, 53, 674-682.

14. Lin, D.C.; Wang, M.R.; Koeffler, H.P. Genomic and Epigenomic Aberrations in Esophageal Squamous Cell Carcinoma and Implications for Patients. Gastroenterology 2018, 154, 374-389. [CrossRef]

15. Nagengast, W.B.; Hartmans, E.; Garcia-Allende, P.B.; Peters, F.T.M.; Linssen, M.D.; Koch, M.; Koller, M.; Tjalma, J.J.J.; Karrenbeld, A.; Jorritsma-Smit, A.; et al. Near-infrared fluorescence molecular endoscopy detects dysplastic oesophageal lesions using topical and systemic tracer of vascular endothelial growth factor A. Gut 2019, 68, 7-10. [CrossRef] [PubMed]

16. Shih, C.H.; Ozawa, S.; Ando, N.; Ueda, M.; Kitajima, M. Vascular endothelial growth factor expression predicts outcome and lymph node metastasis in squamous cell carcinoma of the esophagus. Clin. Cancer Res. 2000, 6, 1161-1168.

17. Mukherjee, T.; Kumar, A.; Mathur, M.; Chattopadhyay, T.K.; Ralhan, R. Ets-1 and VEGF expression correlates with tumor angiogenesis, lymph node metastasis, and patient survival in esophageal squamous cell carcinoma. J. Cancer Res. Clin. Oncol. 2003, 129, 430-436. [CrossRef] [PubMed]

18. Kovar, J.L.; Volcheck, W.; Sevick-Muraca, E.; Simpson, M.A.; Olive, D.M. Characterization and performance of a near-infrared 2-deoxyglucose optical imaging agent for mouse cancer models. Anal. Biochem. 2009, 384, 254-262. [CrossRef] [PubMed]

19. Hartmans, E.; Orian-Rousseau, V.; Matzke-Ogi, A.; Karrenbeld, A.; de Groot, D.J.; de Jong, S.; van Dam, G.M.; Fehrmann, R.S.; Nagengast, W.B. Functional genomic mRNA profiling of colorectal adenomas: Identification and in vivo validation of CD44 and splice variant CD44v6 as molecular imaging targets. Theranostics 2017, 7, 482-492. [CrossRef] [PubMed]

20. Fehrmann, R.S.; Karjalainen, J.M.; Krajewska, M.; Westra, H.J.; Maloney, D.; Simeonov, A.; Pers, T.H.; Hirschhorn, J.N.; Jansen, R.C.; Schultes, E.A.; et al. Gene expression analysis identifies global gene dosage sensitivity in cancer. Nat. Genet. 2015, 47, 115-125 [CrossRef] [PubMed]

21. Zhang, Y.; Jin, X.; Wang, Z.; Zhang, X.; Liu, S.; Liu, G. Downregulation of SNHG1 suppresses cell proliferation and invasion by regulating Notch signaling pathway in esophageal squamous cell cancer. Cancer Biomark. 2017, 21, 89-96. [CrossRef] [PubMed]

22. Qi, B.; Wang, Y.; Chen, Z.J.; Li, X.N.; Qi, Y.; Yang, Y.; Cui, G.H.; Guo, H.Z.; Li, W.H.; Zhao, S. Down-regulation of miR-30a-3p/5p promotes esophageal squamous cell carcinoma cell proliferation by activating the Wnt signaling pathway. World J. Gastroenterol. 2017, 23, 7965-7977. [CrossRef] [PubMed]

23. Cubas, R.; Zhang, S.; Li, M.; Chen, C.; Yao, Q. Trop2 expression contributes to tumor pathogenesis by activating the ERK MAPK pathway. Mol. Cancer 2010, 9, 253. [CrossRef] [PubMed]

24. Nakashima, K.; Shimada, H.; Ochiai, T.; Kuboshima, M.; Kuroiwa, N.; Okazumi, S.; Matsubara, H.; Nomura, F.; Takiguchi, M.; Hiwasa, T. Serological identification of TROP2 by recombinant cDNA expression cloning using sera of patients with esophageal squamous cell carcinoma. Int. J. Cancer 2004, 112, 1029-1035. [CrossRef] [PubMed]

25. Bardia, A.; Messersmith, W.A.; Kio, E.A.; Berlin, J.D.; Vahdat, L.; Masters, G.A.; Moroose, R.; Santin, A.D.; Kalinsky, K.; Picozzi, V.; et al. Sacituzumab govitecan, a Trop-2-directed antibody-drug conjugate, for patients with epithelial cancer: Final safety and efficacy results from the phase I/II IMMU-132-01 basket trial. Ann. Oncol. 2021, 32, 746-756. [CrossRef]

26. Kim, Y.H.; Jeong, D.C.; Pak, K.; Han, M.E.; Kim, J.Y.; Liangwen, L.; Kim, H.J.; Kim, T.W.; Kim, T.H.; Hyun, D.W.; et al. SLC2A2 (GLUT2) as a novel prognostic factor for hepatocellular carcinoma. Oncotarget 2017, 8, 68381-68392. [CrossRef] [PubMed]

27. Choi, W.H.; Yoo, I.E.R.; Kim, T.J.; Lee, K.Y.; Kim, Y.K. Is the Glut expression related to FDG uptake in PET/CT of non-small cell lung cancer patients? Technol. Health Care 2015, 23 (Suppl. S2), 311-318. [CrossRef]

28. Nakashima, T.; Takayama, Y.; Nishie, A.; Asayama, Y.; Baba, S.; Yamashita, Y.; Shirabe, K.; Kubo, Y.; Hida, T.; Honda, H. Hepatocellular adenoma showing high uptake of (18)F-fluorodeoxyglucose (FDG) via an increased expression of glucose transporter 2 (GLUT-2). Clin. Imaging 2014, 38, 888-891. [CrossRef] 
29. Van den Abbeele, A.D.; Gatsonis, C.; de Vries, D.J.; Melenevsky, Y.; Szot-Barnes, A.; Yap, J.T.; Godwin, A.K.; Rink, L.; Huang, M.; Blevins, M.; et al. ACRIN 6665/RTOG 0132 phase II trial of neoadjuvant imatinib mesylate for operable malignant gastrointestinal stromal tumor: Monitoring with 18F-FDG PET and correlation with genotype and GLUT4 expression. J. Nucl. Med. 2012, 53, 567-574. [CrossRef]

30. Zhou, J.C.; Zhang, J.J.; Zhang, W.; Ke, Z.Y.; Ma, L.G.; Liu, M. Expression of GLUT-1 in nasopharyngeal carcinoma and its clinical significance. Eur. Rev. Med. Pharmacol. Sci. 2017, 21, 4891-4895.

31. Xie, B.W.; Mol, I.M.; Keereweer, S.; van Beek, E.R.; Que, I.; Snoeks, T.J.; Chan, A.; Kaijzel, E.L.; Löwik, C.W. Dual-wavelength imaging of tumor progression by activatable and targeting near-infrared fluorescent probes in a bioluminescent breast cancer model. PLoS ONE 2012, 7, e31875. [CrossRef]

32. Cancer Genome Atlas Research Network; Analysis Working Group: Asan University; BC Cancer Agency; Brigham and Women's Hospital; Broad Institute; Brown University; Case Western Reserve University; Dana-Farber Cancer Institute; Duke University; Greater Poland Cancer Centre; et al. Integrated genomic characterization of oesophageal carcinoma. Nature 2017, 541, 169-175. [CrossRef] [PubMed]

33. Hao, J.J.; Lin, D.C.; Dinh, H.Q.; Mayakonda, A.; Jiang, Y.Y.; Chang, C.; Jiang, Y.; Lu, C.C.; Shi, Z.Z.; Xu, X.; et al. Spatial intratumoral heterogeneity and temporal clonal evolution in esophageal squamous cell carcinoma. Nat. Genet. 2016, 48, 1500-1507. [CrossRef]

34. Chen, J.; Jiang, Y.; Chang, T.S.; Joshi, B.; Zhou, J.; Rubenstein, J.H.; Wamsteker, E.J.; Kwon, R.S.; Appelman, H.; Beer, D.G.; et al. Multiplexed endoscopic imaging of Barrett's neoplasia using targeted fluorescent heptapeptides in a phase 1 proof-of-concept study. Gut 2021, 70, 1010-1013. [CrossRef] [PubMed]

35. Barrett, T.; Wilhite, S.E.; Ledoux, P.; Evangelista, C.; Kim, I.F.; Tomashevsky, M.; Marshall, K.A.; Phillippy, K.H.; Sherman, P.M.; Holko, M.; et al. NCBI GEO: Archive for functional genomics data sets-update. Nucleic Acids Res. 2013, 41, D991-D995. [CrossRef] [PubMed]

36. Koller, M.; Hartmans, E.; de Groot, D.J.A.; Zhao, X.J.; van Dam, G.M.; Nagengast, W.B.; Fehrmann, R.S.N. Data-driven prioritization and review of targets for molecular-based theranostic approaches in pancreatic cancer. J. Nucl. Med. 2017, 58, 1899-1903. [CrossRef]

37. Kimchi, E.T.; Posner, M.C.; Park, J.O.; Darga, T.E.; Kocherginsky, M.; Karrison, T.; Hart, J.; Smith, K.D.; Mezhir, J.J.; Weichselbaum, R.R.; et al. Progression of Barrett's metaplasia to adenocarcinoma is associated with the suppression of the transcriptional programs of epidermal differentiation. Cancer Res. 2005, 65, 3146-3154. [CrossRef]

38. Stairs, D.B.; Nakagawa, H.; Klein-Szanto, A.; Mitchell, S.D.; Silberg, D.G.; Tobias, J.W.; Lynch, J.P.; Rustgi, A.K. Cdx1 and c-Myc foster the initiation of transdifferentiation of the normal esophageal squamous epithelium toward Barrett's esophagus. PLoS ONE 2008, 3, e3534. [CrossRef] [PubMed]

39. Wang, Q.; Ma, C.; Kemmner, W. Wdr66 is a novel marker for risk stratification and involved in epithelial-mesenchymal transition of esophageal squamous cell carcinoma. BMC Cancer 2013, 13, 137. [CrossRef]

40. Lee, J.J.; Natsuizaka, M.; Ohashi, S.; Wong, G.S.; Takaoka, M.; Michaylira, C.Z.; Budo, D.; Tobias, J.W.; Kanai, M.; Shirakawa, Y.; et al. Hypoxia activates the cyclooxygenase-2-prostaglandin E synthase axis. Carcinogenesis 2010, 31, 427-434. [CrossRef]

41. Yu, K.; Ganesan, K.; Tan, L.K.; Laban, M.; Wu, J.; Zhao, X.D.; Li, H.; Leung, C.H.; Zhu, Y.; Wei, C.L.; et al. A precisely regulated gene expression cassette potently modulates metastasis and survival in multiple solid cancers. PLoS Genet. 2008, 4, e1000129. [CrossRef]

42. Hyland, P.L.; Zhang, H.; Yang, Q.; Yang, H.H.; Hu, N.; Lin, S.W.; Su, H.; Wang, L.; Wang, C.; Ding, T.; et al. Pathway, in silico and tissue-specific expression quantitative analyses of oesophageal squamous cell carcinoma genome-wide association studies data. Int. J. Epidemiol. 2016, 45, 206-220. [CrossRef]

43. Aoyagi, K.; Minashi, K.; Igaki, H.; Tachimori, Y.; Nishimura, T.; Hokamura, N.; Ashida, A.; Daiko, H.; Ochiai, A.; Muto, M.; et al. Artificially induced epithelial-mesenchymal transition in surgical subjects: Its implications in clinical and basic cancer research. PLoS ONE 2011, 6, e18196. [CrossRef]

44. Chen, K.; Li, Y.; Dai, Y.; Li, J.; Qin, Y.; Zhu, Y.; Zeng, T.; Ban, X.; Fu, L.; Guan, X.Y. Characterization of tumor suppressive function of cornulin in esophageal squamous cell carcinoma. PLoS ONE 2013, 8, e68838. [CrossRef] [PubMed]

45. Matsuyama, Y.; Suzuki, M.; Arima, C.; Huang, Q.M.; Tomida, S.; Takeuchi, T.; Sugiyama, R.; Itoh, Y.; Yatabe, Y.; Goto, H.; et al. Proteasomal non-catalytic subunit PSMD2 as a potential therapeutic target in association with various clinicopathologic features in lung adenocarcinomas. Mol. Carcinog. 2011, 50, 301-309. [CrossRef]

46. Davis, H.; Irshad, S.; Bansal, M.; Rafferty, H.; Boitsova, T.; Bardella, C.; Jaeger, E.; Lewis, A.; Freeman-Mills, L.; Giner, F.C.; et al. Aberrant epithelial GREM1 expression initiates colonic tumorigenesis from cells outside the stem cell niche. Nat. Med. 2015, 21, 62-70. [CrossRef]

47. Van Vlodrop, I.J.; Baldewijns, M.M.; Smits, K.M.; Schouten, L.J.; van Neste, L.; van Criekinge, W.; van Poppel, H.; Lerut, E.; Schuebel, K.E.; Ahuja, N.; et al. Prognostic significance of Gremlin1 (GREM1) promoter CpG island hypermethylation in clear cell renal cell carcinoma. Am. J. Pathol. 2010, 176, 575-584. [CrossRef]

48. Xu, G.; Tang, S.; Yang, J.; Chen, K.; Kang, J.; Zhao, G.; Feng, F.; Yang, X.; Zhao, L.; Lu, Q.; et al. BMP7 expression in esophageal squamous cell carcinoma and its potential role in modulating metastasis. Dig. Dis. Sci. 2013, 58, 1871-1879. [CrossRef]

49. Motoyama, K.; Tanaka, F.; Kosaka, Y.; Mimori, K.; Uetake, H.; Inoue, H.; Sugihara, K.; Mori, M. Clinical significance of BMP7 in human colorectal cancer. Ann. Surg. Oncol. 2008, 15, 1530-1537. [CrossRef] 
50. Alarmo, E.L.; Pärssinen, J.; Ketolainen, J.M.; Savinainen, K.; Karhu, R.; Kallioniemi, A. BMP7 influences proliferation, migration, and invasion of breast cancer cells. Cancer Lett. 2009, 275, 35-43. [CrossRef] [PubMed]

51. Wang, T.; Han, S.; Wu, Z.; Han, Z.; Yan, W.; Liu, T.; Wei, H.; Song, D.; Zhou, W.; Yang, X.; et al. XCR1 promotes cell growth and migration and is correlated with bone metastasis in non-small cell lungcancer. Biochem. Biophys. Res. Commun. 2015, 464, 635-641. [CrossRef] [PubMed]

52. Kim, M.; Rooper, L.; Xie, J.; Rayahin, J.; Burdette, J.E.; Kajdacsy-Balla, A.A.; Barbolina, M.V. The lymphotactin receptor is expressed in epithelial ovarian carcinoma and contributes to cell migration and proliferation. Mol. Cancer Res. 2012, 10, 1419-1429. [CrossRef] [PubMed]

53. Louie, S.M.; Grossman, E.A.; Crawford, L.A.; Ding, L.; Camarda, R.; Huffman, T.R.; Miyamoto, D.K.; Goga, A.; Weerapana, E.; Nomura, D.K. GSTP1 Is a Driver of Triple-Negative Breast Cancer Cell Metabolism and Pathogenicity. Cell Chem. Biol. 2016, 23, 567-578. [CrossRef]

54. Yamamoto, Y.; Konishi, H.; Ichikawa, D.; Arita, T.; Shoda, K.; Komatsu, S.; Shiozaki, A.; Ikoma, H.; Fujiwara, H.; Okamoto, K.; et al. Significance of GSTP1 for predicting the prognosis and chemotherapeutic efficacy in esophageal squamous cell carcinoma. Oncol. Rep. 2013, 30, 1687-1694. [CrossRef]

55. Allameh, A.; Rasmi, Y.; Nasseri-Moghaddam, S.; Tavangar, S.M.; Sharifi, R.; Sadreddini, M. Immunohistochemical analysis of selected molecular markers in esophagus precancerous, adenocarcinoma and squamous cell carcinoma in Iranian subjects. Cancer Epidemiol. 2009, 33, 79-84. [CrossRef]

56. Zhang, R.; Kang, K.A.; Piao, M.J.; Kim, K.C.; Zheng, J.; Yao, C.W.; Cha, J.W.; Maeng, Y.H.; Chang, W.Y.; Moon, P.G.; et al. Epigenetic alterations are involved in the overexpression of glutathione S-transferase $\pi-1$ in human colorectal cancers. Int. J. Oncol. 2014, 45, 1275-1283. [CrossRef]

57. Fujikawa, Y.; Urano, Y.; Komatsu, T.; Hanaoka, K.; Kojima, H.; Terai, T.; Inoue, H.; Nagano, T. Design and synthesis of highly sensitive fluorogenic substrates for glutathione S-transferase and application for activity imaging in living cells. J. Am. Chem. Soc. 2008, 130, 14533-14543. [CrossRef]

58. Jin, X.; Zhai, B.; Fang, T.; Guo, X.; Xu, L. FXR1 is elevated in colorectal cancer and acts as an oncogene. Tumour Biol. 2016, 37, 2683-2690. [CrossRef] [PubMed]

59. Qian, J.; Hassanein, M.; Hoeksema, M.D.; Harris, B.K.; Zou, Y.; Chen, H.; Lu, P.; Eisenberg, R.; Wang, J.; Espinosa, A.; et al. The RNA binding protein FXR1 is a new driver in the 3q26-29 amplicon and predicts poor prognosis in human cancers. Proc. Natl. Acad. Sci. USA 2015, 112, 3469-3474. [CrossRef]

60. Michifuri, Y.; Hirohashi, Y.; Torigoe, T.; Miyazaki, A.; Fujino, J.; Tamura, Y.; Tsukahara, T.; Kanaseki, T.; Kobayashi, J.; Sasaki, T.; et al. Small proline-rich protein-1B is overexpressed in human oral squamous cell cancer stem-like cells and is related to their growth through activation of MAP kinase signal. Biochem. Biophys. Res. Commun. 2013, 439, 96-102. [CrossRef] [PubMed]

61. Pu, X.; Wang, J.; Li, W.; Fan, W.; Wang, L.; Mao, Y.; Yang, S.; Liu, S.; Xu, J.; Lv, Z.; et al. COPB2 promotes cell proliferation and tumorigenesis through up-regulating YAP1 expression in lung adenocarcinoma cells. Biomed. Pharmacother. 2018, 103, 373-380. [CrossRef] [PubMed]

62. Kim, B.K.; Yoo, H.I.; Kim, I.; Park, J.; Kim Yoon, S. FZD6 expression is negatively regulated by miR-199a-5p in human colorectal cancer. BMB Rep. 2015, 48, 360-366. [CrossRef]

63. Yan, J.; Liu, T.; Zhou, X.; Dang, Y.; Yin, C.; Zhang, G. FZD6, targeted by miR-21, represses gastric cancer cell proliferation and migration via activating non-canonical wnt pathway. Am. J. Transl. Res. 2016, 8, 2354-2364.

64. Wang, L.; Chen, S.; Xue, M.; Zhong, J.; Wang, X.; Gan, L.; Lam, E.K.; Liu, X.; Zhang, J.; Zhou, T.; et al. Homeobox D10 gene, a candidate tumor suppressor, is downregulated through promoter hypermethylation and associated with gastric carcinogenesis. Mol. Med. 2012, 18, 389-400. [CrossRef] [PubMed]

65. Lee, P.; Jiang, S.; Li, Y.; Yue, J.; Gou, X.; Chen, S.Y.; Zhao, Y.; Schober, M.; Tan, M.; Wu, X. Phosphorylation of Pkp1 by RIPK4 regulates epidermal differentiation and skin tumorigenesis. EMBO J. 2017, 36, 1963-1980. [CrossRef]

66. Hamamoto, R.; Toyokawa, G.; Nakakido, M.; Ueda, K.; Nakamura, Y. SMYD2-dependent HSP90 methylation promotes cancer cell proliferation by regulating the chaperone complex formation. Cancer Lett. 2014, 351, 126-133. [CrossRef] [PubMed]

67. Chan, C.T.; Paulmurugan, R.; Gheysens, O.S.; Kim, J.; Chiosis, G.; Gambhir, S.S. Molecular imaging of the efficacy of heat shock protein 90 inhibitors in living subjects. Cancer Res. 2008, 68, 216-226. [CrossRef] [PubMed]

68. Lau, D.; Guo, L.; Chan, A.; Wu, R. SPR1. An early molecular marker for bronchial carcinogenesis. Methods Mol. Med. 2003, 75, 397-403. [PubMed]

69. Matsuyama, A.; Hisaoka, M.; Hashimoto, H. PLAG1 expression in mesenchymal tumors: An immunohistochemical study with special emphasis on the pathogenetical distinction between soft tissue myoepithelioma and pleomorphic adenoma of the salivary gland. Pathol. Int. 2012, 62, 1-7. [CrossRef]

70. Declercq, J.; Van Dyck, F.; Braem, C.V.; Van Valckenborgh, I.C.; Voz, M.; Wassef, M.; Schoonjans, L.; Van Damme, B.; Fiette, L.; Van de Ven, W.J. Salivary gland tumors in transgenic mice with targeted PLAG1 proto-oncogene overexpression. Cancer Res. 2005, 65, 4544-4553. [CrossRef] [PubMed]

71. Lauenborg, B.; Kopp, K.; Krejsgaard, T.; Eriksen, K.W.; Geisler, C.; Dabelsteen, S.; Gniadecki, R.; Zhang, Q.; Wasik, M.A.; Woetmann, A.; et al. Programmed cell death-10 enhances proliferation and protects malignant T cells from apoptosis. APMIS 2010, 118, 719-728. [CrossRef] 
72. Wang, Y.; Godin-Heymann, N.; Dan Wang, X.; Bergamaschi, D.; Llanos, S.; Lu, X. ASPP1 and ASPP2 bind active RAS, potentiate RAS signalling and enhance p53 activity in cancer cells. Cell Death Differ. 2013, 20, 525-534. [CrossRef]

73. O'Byrne, K.; Paquet, N.; Box, J.K.; Adams, M.; Richard, D. 17P Examination of EXOSC4 as a new prognostic marker and a novel therapeutic avenue in lung adenocarcinoma. J. Thorac. Oncol. 2016, 11 (Suppl. S4), 63. [CrossRef]

74. Hasan, R.; Srivastava, G.; Alyass, A.; Sharma, R.; Saraya, A.; Chattopadhyay, T.K.; DattaGupta, S.; Walfish, P.G.; Chauhan, S.S.; Ralhan, R. Prediction of recurrence free survival for esophageal cancer patients using a protein signature based risk model. Oncotarget 2016, 5, 18. [CrossRef]

75. You, X.J.; Bryant, P.J.; Jurnak, F.; Holcombe, R.F. Expression of Wnt pathway components frizzled and disheveled in colon cancer arising in patients with inflammatory bowel disease. Oncol. Rep. 2007, 18, 691-694. [CrossRef] [PubMed]

76. Zhao, H.; Zhao, Y.; Jiang, G.; Zhang, X.; Zhang, Y.; Dong, Q.; Luan, L.; Papavassiliou, P.; Wang, E.; Wang, E. Dishevelled-3 activates p65 to upregulate p120-catenin transcription via a p38-dependent pathway in non-small cell lung cancer. Mol. Carcinog. 2015, 54 (Suppl. S1), E112-E121. [CrossRef]

77. Ogane, N.; Yasuda, M.; Shimizu, M.; Miyazawa, M.; Kamoshida, S.; Ueda, A.; Takata, K.; Sakuma, Y.; Miyagi, Y.; Kameda, Y. Clinicopathological implications of expressions of hypoxia-related molecules in esophageal superficial squamous cell carcinoma. Ann. Diagn. Pathol. 2010, 14, 23-29. [CrossRef] [PubMed]

78. Goos, J.A.; de Cuba, E.M.; Coupé, V.M.; Diosdado, B.; Delis-Van Diemen, P.M.; Karga, C.; Beliën, J.A.; Menke-Van der Houven van Oordt, C.W.; Geldof, A.A.; Meijer, G.A.; et al. Glucose Transporter 1 (SLC2A1) and Vascular Endothelial Growth Factor A (VEGFA) Predict Survival After Resection of Colorectal Cancer Liver Metastasis. Ann. Surg. 2016, 263, 138-145. [CrossRef] [PubMed]

79. Wellberg, E.A.; Johnson, S.; Finlay-Schultz, J.; Lewis, A.S.; Terrell, K.L.; Sartorius, C.A.; Abel, E.D.; Muller, W.J.; Anderson, S.M. The glucose transporter GLUT1 is required for ErbB2-induced mammary tumorigenesis. Breast Cancer Res. 2016, $18,131$. [CrossRef]

80. Sohn, C.H.; Park, S.P.; Choi, S.H.; Park, S.H.; Kim, S.; Xu, L.; Kim, S.H.; Hur, J.A.; Choi, J.; Choi, T.H. MRI molecular imaging using GLUT1 antibody-Fe3O4 nanoparticles in the hemangioma animal model for differentiating infantile hemangioma from vascular malformation. Nanomedicine 2015, 11, 127-135. [CrossRef]

81. Jin, Z.L.; Pei, H.; Xu, Y.H.; Yu, J.; Deng, T. The SUMO-specific protease SENP5 controls DNA damage response and promotes tumorigenesis in hepatocellular carcinoma. Eur. Rev. Med. Pharmacol. Sci. 2016, 20, 3566-3573.

82. Chen, C.F.; Hsu, E.C.; Lin, K.T.; Tu, P.H.; Chang, H.W.; Lin, C.H.; Chen, Y.J.; Gu, D.L.; Lin, C.H.; Wu, J.Y.; et al. Overlapping highresolution copy number alterations in cancer genomes identified putative cancer genes in hepatocellular carcinoma. Hepatology 2010, 52, 1690-1701. [CrossRef] [PubMed]

83. Mourskaia, A.A.; Amir, E.; Dong, Z.; Tiedemann, K.; Cory, S.; Omeroglu, A.; Bertos, N.; Ouellet, V.; Clemons, M.; Scheffer, G.L.; et al. ABCC5 supports osteoclast formation and promotes breast cancer metastasis to bone. Breast Cancer Res. 2012, 14, R149. [CrossRef] [PubMed]

84. Tóth, K.; Wasserkort, R.; Sipos, F.; Kalmár, A.; Wichmann, B.; Leiszter, K.; Valcz, G.; Juhász, M.; Miheller, P.; Patai, Á.V.; et al. Detection of Methylated Septin 9 in Tissue and Plasma of Colorectal Patients with Neoplasia and the Relationship to the Amount of Circulating Cell-Free DNA. PLoS ONE 2014, 9, e115415. [CrossRef]

85. Liu, M.; Shen, S.; Chen, F.; Yu, W.; Yu, L. Linking the septin expression with carcinogenesis. Mol. Biol. Rep. 2010, 37, 3601-3608. [CrossRef]

86. Name, N.; Boonpipattanapong, T.; Palanusont, A.; Maneechay, W.; Sangkhathat, S. Alteration of Leptin and Adiponectin in Multistep Colorectal Tumorigenesis. Asian Pac. J. Cancer Prev. 2016, 17, 2119-2123.

87. Cai, X.Y.; Wang, X.F.; Li, J.; Dong, J.N.; Liu, J.Q.; Li, N.P.; Yun, B.; Xia, R.L. Overexpression of CD39 and high tumoral CD39+/CD8+ ratio are associated with adverse prognosis in resectable gastric cancer. Int. J. Clin. Exp. Pathol. 2015, 8, 14757-14764. [PubMed]

88. Cai, X.Y.; Ni, X.C.; Yi, Y.; He, H.W.; Wang, J.X.; Fu, Y.P.; Sun, J.; Zhou, J.; Cheng, Y.F.; Jin, J.J. Overexpression of CD39 in hepatocellular carcinoma is an independent indicator of poor outcome after radical resection. Medicine 2016, 95, e4989. [CrossRef] [PubMed]

89. Luan, S.L.; Boulanger, E.; Ye, H.; Chanudet, E.; Johnson, N.; Hamoudi, R.A.; Bacon, C.M.; Liu, H.; Huang, Y.; Said, J.; et al. Primary effusion lymphoma: Genomic profiling revealed amplification of SELPLG and CORO1C encoding for proteins important for cell migration. J. Pathol. 2010, 222, 166-179. [CrossRef] [PubMed]

90. Fu, W.; Sun, J.; Huang, G.; Liu, J.C.; Kaufman, A.; Ryan, R.J.; Ramanathan, S.Y.; Venkatesh, T.; Singh, B. Squamous Cell Carcinomarelated Oncogene (SCCRO) Family Members Regulate Cell Growth and Proliferation through Their Cooperative and Antagonistic Effects on Cullin Neddylation. J. Biol. Chem. 2016, 291, 6200-6217. [CrossRef] [PubMed]

91. De Andrea, C.E.; Zhu, J.F.; Jin, H.; Bovée, J.V.; Jones, K.B. Cell cycle deregulation and mosaic loss of Ext1 drive peripheral chondrosarcomagenesis in the mouse and reveal an intrinsic cilia deficiency. J. Pathol. 2015, 236, 210-218. [CrossRef] [PubMed]

92. Aihara, H.; Nakagawa, T.; Mizusaki, H.; Yoneda, M.; Kato, M.; Doiguchi, M.; Imamura, Y.; Higashi, M.; Ikura, T.; Hayashi, T.; et al. Histone H2A T120 Phosphorylation Promotes Oncogenic Transformation via Upregulation of Cyclin D1. Mol. Cell. 2016, 64, 176-188. [CrossRef]

93. Jullien, D.; Vignard, J.; Fedor, Y.; Béry, N.; Olichon, A.; Crozatier, M.; Erard, M.; Cassard, H.; Ducommun, B.; Salles, B.; et al. Chromatibody, a novel non-invasive molecular tool to explore and manipulate chromatin in living cells. J. Cell Sci. 2016, $129,2673-2683$. 
94. Hu, J.; Zhang, L.C.; Song, X.; Lu, J.R.; Jin, Z. KRT6 interacting with notch1 contributes to progression of renal cell carcinoma, and aliskiren inhibits renal carcinoma cell lines proliferation in vitro. Int. J. Clin. Exp. Pathol. 2015, 8, 9182-9188. [PubMed]

95. Sun, Y.; Li, H. Functional characterization of SAG/RBX2/ROC2/RNF7, an antioxidant protein and an E3 ubiquitin ligase. Protein Cell 2013, 4, 103-116. [CrossRef] [PubMed]

96. Milosevic, V.S.; Vukmirovic, F.C.; Krstic, M.S.; Zindovic, M.M.; Lj Stojanovic, D.; Jancic, S.A. Involvement of leptin receptors expression in proliferation and neoangiogenesis in colorectal carcinoma. J. BUON 2015, 20, 100-108. [PubMed]

97. Howard, J.M.; Cathcart, M.C.; Healy, L.; Beddy, P.; Muldoon, C.; Pidgeon, G.P.; Reynolds, J.V. Leptin and adiponectin receptor expression in oesophageal cancer. Br. J. Surg. 2014, 101, 643-652. [CrossRef] [PubMed]

98. Luque-García, J.L.; Martínez-Torrecuadrada, J.L.; Epifano, C.; Cañamero, M.; Babel, I.; Casal, J.I. Differential protein expression on the cell surface of colorectal cancer cells associated to tumor metastasis. Proteomics 2010, 10, 940-952. [CrossRef] [PubMed]

99. Lin, Y.C.; Wu, M.Y.; Li, D.R.; Wu, X.Y.; Zheng, R.M. Prognostic and clinicopathological features of E-cadherin, alpha-catenin, beta-catenin, gamma-catenin and cyclin D1 expression in human esophageal squamous cell carcinoma. World J. Gastroenterol. 2004, 10, 3235-3239. [CrossRef]

100. Kim, C.Y.; Jung, W.Y.; Lee, H.J.; Kim, H.K.; Kim, A.; Shin, B.K. Proteomic analysis reveals overexpression of moesin and cytokeratin 17 proteins in colorectal carcinoma. Oncol. Rep. 2012, 27, 608-620. [PubMed]

101. Hu, H.; Xu, D.H.; Huang, X.X.; Zhu, C.C.; Xu, J.; Zhang, Z.Z.; Zhao, G. Keratin17 Promotes Tumor Growth and is Associated with Poor Prognosis in Gastric Cancer. J. Cancer 2018, 9, 346-357. [CrossRef]

102. Simpson, J.A.; Al-Attar, A.; Watson, N.F.; Scholefield, J.H.; Ilyas, M.; Durrant, L.G. Intratumoral T cell infiltration, MHC class I and STAT1 as biomarkers of good prognosis in colorectal cancer. Gut 2010, 59, 926-933. [CrossRef]

103. Zhang, C.; Hou, D.; Wei, H.; Zhao, M.; Yang, L.; Liu, Q.; Zhang, X.; Gong, Y.; Shao, C. Lack of interferon- $\gamma$ receptor results in a microenvironment favorable for intestinal tumorigenesis. Oncotarget 2016, 7, 42099-42109. [CrossRef]

104. Miyazaki, T.; Kato, H.; Nakajima, M.; Sohda, M.; Fukai, Y.; Masuda, N.; Manda, R.; Fukuchi, M.; Tsukada, K.; Kuwano, H. FAK overexpression is correlated with tumour invasiveness and lymph node metastasis in oesophageal squamous cell carcinoma. $\mathrm{Br}$. J. Cancer 2003, 89, 140-145. [CrossRef]

105. Cance, W.G.; Harris, J.E.; Iacocca, M.V.; Roche, E.; Yang, X.; Chang, J.; Simkins, S.; Xu, L. Immunohistochemical analyses of focal adhesion kinase expression in benign and malignant human breast and colon tissues: Correlation with preinvasive and invasive phenotypes. Clin. Cancer Res. 2000, 6, 2417-2423.

106. Kessler, B.E.; Sharma, V.; Zhou, Q.; Jing, X.; Pike, L.A.; Kerege, A.A.; Sams, S.B.; Schweppe, R.E. FAK Expression, Not Kinase Activity, Is a Key Mediator of Thyroid Tumorigenesis and Protumorigenic Processes. Mol. Cancer Res. 2016, 14, 869-882. [CrossRef]

107. Liao, X.; Lu, S.; Wu, Y.; Xu, W.; Zhuo, Y.; Peng, Q.; Li, B.; Zhang, L.; Wang, Y. The effect of differentiation induction on FAK and Src activity in live HMSCs visualized by FRET. PLoS ONE 2013, 8, e72233. [CrossRef]

108. Zhang, J.X.; Tong, Z.T.; Yang, L.; Wang, F.; Chai, H.P.; Zhang, F.; Xie, M.R.; Zhang, A.L.; Wu, L.M.; Hong, H.; et al. PITX2: A promising predictive biomarker of patients' prognosis and chemoradioresistance in esophageal squamous cell carcinoma. Int. J. Cancer 2013, 132, 2567-2577. [CrossRef]

109. Huang, Y.; Guigon, C.J.; Fan, J.; Cheng, S.Y.; Zhu, G.Z. Pituitary homeobox 2 (PITX2) promotes thyroid carcinogenesis by activation of cyclin D2. Cell Cycle 2010, 9, 1333-1341. [CrossRef] [PubMed]

110. Kim, A.Y.; Lim, B.; Choi, J.; Kim, J. The TFG-TEC oncoprotein induces transcriptional activation of the human $\beta$-enolase gene via chromatin modification of the promoter region. Mol. Carcinog. 2016, 55, 1411-1423. [CrossRef] [PubMed]

111. Liu, W.; Li, Z.; Xu, W.; Wang, Q.; Yang, S. Humoral autoimmune response to IGF2 mRNA-binding protein (IMP2/p62) and its tissue-specific expression in colon cancer. Scand. J. Immunol. 2013, 77, 255-260. [CrossRef] [PubMed]

112. Ye, S.; Song, W.; Xu, X.; Zhao, X.; Yang, L. IGF2BP2 promotes colorectal cancer cell proliferation and survival through interfering with RAF-1 degradation by miR-195. FEBS Lett. 2016, 590, 1641-1650. [CrossRef] [PubMed]

113. Barghash, A.; Golob-Schwarzl, N.; Helms, V.; Haybaeck, J.; Kessler, S.M. Elevated expression of the IGF2 mRNA binding protein 2 (IGF2BP2/IMP2) is linked to short survival andmetastasis in esophageal adenocarcinoma. Oncotarget 2016, 7, 49743-49750. [CrossRef]

114. Yachida, S.; Wood, L.D.; Suzuki, M.; Takai, E.; Totoki, Y.; Kato, M.; Luchini, C.; Arai, Y.; Nakamura, H.; Hama, N.; et al. Genomic Sequencing Identifies ELF3 as a Driver of Ampullary Carcinoma. Cancer Cell 2016, 29, 229-240. [CrossRef]

115. Ding, Y.; Shimada, Y.; Gorrin-Rivas, M.J.; Itami, A.; Li, Z.; Hong, T.; Maeda, M.; Komoto, I.; Kawabe, A.; Kaganoi, J.; et al. Clinicopathological significance of human macrophage metalloelastase expression in esophageal squamous cell carcinoma. Oncology 2002, 63, 378-384. [CrossRef]

116. Zheng, J.; Chu, D.; Wang, D.; Zhu, Y.; Zhang, X.; Ji, G.; Zhao, H.; Wu, G.; Du, J.; Zhao, Q. Matrix metalloproteinase-12 is associated with overall survival in Chinese patients with gastric cancer. J. Surg. Oncol. 2013, 107, 746-751. [CrossRef]

117. Xu, J.E.C.; Yao, Y.; Ren, S.; Wang, G.; Jin, H. Matrix metalloproteinase expression and molecular interaction network analysis in gastric cancer. Oncol. Lett. 2016, 12, 2403-2408. [CrossRef]

118. Zhu, Y.H.; Yang, F.; Zhang, S.S.; Zeng, T.T.; Xie, X.; Guan, X.Y. High expression of biglycan is associated with poor prognosis in patients with esophageal squamous cell carcinoma. Int. J. Clin. Exp. Pathol. 2013, 6, 2497-2505. [PubMed]

119. Wang, B.; Li, G.X.; Zhang, S.G.; Wang, Q.; Wen, Y.G.; Tang, H.M.; Zhou, C.Z.; Xing, A.Y.; Fan, J.W.; Yan, D.W.; et al. Biglycan expression correlates with aggressiveness and poor prognosis of gastric cancer. Exp. Biol. Med. 2011, 236, 1247-1253. [CrossRef] 
120. Xing, X.; Gu, X.; Ma, T. Knockdown of biglycan expression by RNA interference inhibits the proliferation and invasion of, and induces apoptosis in, the HCT116 colon cancer cell line. Mol. Med. Rep. 2015, 12, 7538-7544. [CrossRef]

121. Okayama, A.; Kimura, Y.; Miyagi, Y.; Oshima, T.; Oshita, F.; Ito, H.; Nakayama, H.; Nagashima, T.; Rino, Y.; Masuda, M.; et al. Relationship between phosphorylation of sperm-specific antigen and prognosis of lung adenocarcinoma. J. Proteom. 2016, 139, 60-66. [CrossRef] [PubMed]

122. Hu, H.; Xia, S.H.; Li, A.D.; Xu, X.; Cai, Y.; Han, Y.L.; Wei, F.; Chen, B.S.; Huang, X.P.; Han, Y.S.; et al. Elevated expression of p63 protein in human esophageal squamous cell carcinomas. Int. J. Cancer 2002, 102, 580-583. [CrossRef] [PubMed]

123. Song, Y.; Liu, D.; He, G. TKTL1 and p63 are biomarkers for the poor prognosis of gastric cancer patients. Cancer Biomark. 2015, 15, 591-597. [CrossRef] [PubMed]

124. De Oliveira, D.H.; de Sousa Lopes, M.L.; de Santana Sarmento, D.J.; Queiroz, L.M.; da Costa Miguel, M.C.; da Silveira, E.J. Relationship between the epithelial expression of hMLH1, MDM2, and p63 and lower lip carcinogenesis. J. Oral Pathol. Med. 2014, 43, 357-363. [CrossRef] [PubMed]

125. Schütz, M.; Steinigeweg, D.; Salehi, M.; Kömpe, K.; Schlücker, S. Hydrophilically stabilized gold nanostars as SERS labels for tissue imaging of the tumor suppressor p63 by immuno-SERS microscopy. Chem. Commun. 2011, 47, 4216-4218. [CrossRef] [PubMed]

126. Urzúa-Traslaviña, C.G.; Leeuwenburgh, V.C.; Bhattacharya, A.; Loipfinger, S.; van Vugt, M.A.T.M.; de Vries, E.G.E.; Fehrmann, R.S.N. Improving gene function predictions using independent transcriptional components. Nat. Commun. 2021, $12,1464$. [CrossRef] [PubMed] 